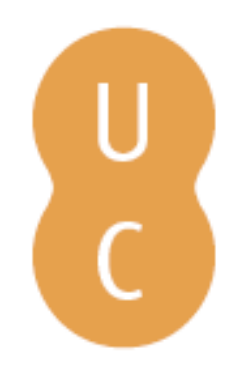

\title{
nombalina
}

O processo de construção da imagem do tirano nas vidas dos Césares de Suetónio
Autor(es):
Brandão, José Luís Lopes
Publicado por: Imprensa da Universidade de Coimbra
URL
persistente:
URI:http://hdl.handle.net/10316.2/34754
DOI:
DOI:http://dx.doi.org/10.14195/978-989-26-0626-2_4

Accessed : $\quad$ 26-Apr-2023 01:16:07

A navegação consulta e descarregamento dos títulos inseridos nas Bibliotecas Digitais UC Digitalis, UC Pombalina e UC Impactum, pressupõem a aceitação plena e sem reservas dos Termos e Condições de Uso destas Bibliotecas Digitais, disponíveis em https://digitalis.uc.pt/pt-pt/termos.

Conforme exposto nos referidos Termos e Condições de Uso, o descarregamento de títulos de acesso restrito requer uma licença válida de autorização devendo o utilizador aceder ao(s) documento(s) a partir de um endereço de IP da instituição detentora da supramencionada licença.

Ao utilizador é apenas permitido o descarregamento para uso pessoal, pelo que o emprego do(s) título(s) descarregado(s) para outro fim, designadamente comercial, carece de autorização do respetivo autor ou editor da obra.

Na medida em que todas as obras da UC Digitalis se encontram protegidas pelo Código do Direito de Autor e Direitos Conexos e demais legislação aplicável, toda a cópia, parcial ou total, deste documento, nos casos em que é legalmente admitida, deverá conter ou fazer-se acompanhar por este aviso. 


\title{
Saberes e poderes no Mundo Antigo
}

Estudos ibero-latino-americanos

\author{
Volume II - Dos poderes
}

Fábio Cerqueira, Ana Teresa Gonçalves, Edalaura Medeiros \& Delfim Leão (Orgs.)

IMPRENSA DA UNIVERSIDADE DE COIMBRA

UNIVERSIDADE FEDERAL DE PELOTAS

UNIVERSIDADE FEDERAL DE GOIÃS 


\title{
O PROCESSO DE CONSTRUÇÃO DA IMAGEM DO TIRANO NAS VIDAS DOS CÉSARES DE SUETÓNIO
}

\author{
José Luís Lopes Brandão \\ Universidade de Coimbra - Portugal
}

As Vidas dos Césares de Suetónio não se apresentam maioritariamente como uma narrativa cronológica: esta tende a restringir-se aos factos relativos à ascensão dos imperadores e à sua morte. Pelo meio, distribuem-se as diversas species (rubricas) relativas aos aspectos que devem ser tratados numa Vida. As rubricas não estão, por seu turno, organizadas por simples acumulação de materiais exemplificativos, como poderia parecer à primeira vista, mas segundo uma certa progressão e em conexão com o todo de cada biografia. Nas secções relativas ao governo dos imperadores, a parte que trataremos neste estudo, vamos encontrar características que já se apresentavam em gérmen no relato das actividades que antecederam a chegada ao poder e que serão completadas (confirmadas ou postas em causa) na narrativa da morte. E estes traços já estão muitas vezes presentes nos antepassados, rubrica com que geralmente se iniciam as Vidas. $^{1}$

Para a descrição dos feitos do governante Suetónio vai colocar os critérios éticos à frente dos cronológicos. E o carácter dos imperadores é avaliado quer pela sua actividade governativa, quer pela vida privada. Uma vez que se trata de ilustração de vícios e virtudes, a progressão procurada tem a ver com a intensidade de determinado traço moral. O biógrafo manifesta claramente 0 intuito de criar uma imagem que se apresenta completa no final. No caso dos maus imperadores, observa-se uma progressão para o vício, e em último lugar tendem a aparecer os comportamentos mais horrendos. Mas temos de ter em conta que superbia, crudelitas, auaritia, libido eram, na altura, elementos convencionais da descrição do tirano. ${ }^{2}$

\section{Vida de Tibério}

No caso de Tibério, a progressão para a tirania é inequívoca. As gradações presentes nesta Vida sugerem que houve criação da imagem do tirano detestado e temido, cruel e sempre temeroso de revoltas. Depois do relato do começo feliz do principado, em que Tibério vive quase como cidadão privado (Tib. 26.1) e conserva uma aparência de liberdade ${ }^{3}$, o biógrafo introduz uma mudança, assinalada por paulatim, no comportamento do imperador (Tib. 33). Começa a manifestar-se o princeps (termo aqui entendido no sentido de tendência para a tirania), embora de modo variado e ainda inclinado sobretudo para o bem público; e nota-se já o 
O processo de construção do imagem do tirano ...

aumento de rigor na aplicação da lei. O déspota começa a crescer ${ }^{4}$, passando a governar com maior firmeza e determinação, como revelam as medidas de contenção de despesas (Tib. 34). A repressão mostra já plena força com a proibição dos ritos egípcios e judaicos e com a expulsão dos astrólogos (Tib. 36). Atinge-se o auge desta fase com as medidas para a restauração da ordem, ilustrada com vários acontecimentos. $^{5}$

Entramos numa fase de visível transição (Tib. 38-40). Suetónio, acaso para acentuar as contradições do príncipe, lembra que ele, durante dois anos, não se ausentou de Roma, embora anunciasse e preparasse contínuas viagens (Tib. 38). Ao narrar a partida de Tibério para a Campânia (Tib. 39), na sequência da morte de Germânico e do filho Druso, Suetónio centra-se na forma milagrosa como o imperador escapou ileso de uma derrocada na gruta de Spelunca, sem retirar as ilações políticas de tal evento. ${ }^{6}$

Consagrar um templo a Júpiter Capitolino em Cápua e outro a Augusto em Nola ${ }^{7}$, era apenas o pretexto oficial da viagem, pois Tibério rumou a Cápreas. 0 motivo que o biógrafo apresenta para a predilecção do imperador por esta ilha está ligado ao carácter do próprio: não se tratava da inegável beleza do lugar, mas da sua inacessibilidade. ${ }^{8}$ O biógrafo procura, assim, acentuar a crescente misantropia do imperador. ${ }^{9} \mathrm{~A}$ instalação definitiva na ilha é o ponto de charneira na evolução do principado de Tibério. Se já atrás (Tib. 33) houve sinais de afirmação do déspota, agora a viragem é completa: entramos na fase negativa do governo. A negligência ou demissão de Tibério em relação às questões políticas é tratada, como faz habitualmente Suetónio nestes assuntos, num breve resumo cheio de generalizações ${ }^{10}$; a narrativa centra-se no estudo do carácter e degradação dos comportamentos:

Ceterum secreti licentiam nanctus et quasi ciuitatis oculis remotis, cuncta simul uitia male diu dissimulata tandem profudit: de quibus singillatim ab exordio referam.

Mas, dado que encontrara a conivência do retiro, e os olhares da cidade, estavam, por assim dizer, afastados, deu largas, de uma assentada, a todos os vícios há longo tempo mal dissimulados. Desses vícios vou eu agora tratar, um por um, desde o início. ${ }^{11}$

Com a afirmação de uitia male diu dissimulata, o biógrafo sugere que toda a vida anterior tem de ser vista a uma nova luz: os vícios já existiam, mas eram dissimulados pela suposta hipocrisia de Tibério. O tratamento per species impõe uma analepse (ou uma série de analepses, para os vários vícios), introduzida pela expressão $a b$ exordium referam. ${ }^{12}$ Começa pela avidez de vinho, que se manifestava já no início da carreira militar. Com um postea, introduz-nos bruscamente no período do principado (Tib. 42.1), e transita da ebriedade para a luxúria (Tib. 42.2). 
O biógrafo, como é seu hábito, usa rumores com valor de prova das depravações ocorridas no secretismo da ilha (Tib. 43). O exílio de Cápreas favorece a criação de mitos em torno da sexualidade do imperador. ${ }^{13}$ Tibério cria à sua volta um teatro pornográfico e mitológico, consonante com o gosto da época encenações que, para o biógrafo, são apenas motivadas pelo voyeurismo do velho depravado: uma clara cedência às versões mais romanescas resultantes da calúnia. Perante a monstruosidade dos factos, o biógrafo parece manifestar alguma incredulidade ${ }^{14}$, mas, apresentados em gradação, surgem os actos de pedofilia a que se entregava pela natura e pela idade; o escandaloso quadro de Parrásio, colocado no quarto de dormir ${ }^{15}$; a violação de um minister de um sacrifício no final da cerimónia; o abuso de matronas, de que é exemplo paradigmático o caso de Malónia, que, como Lucrécia, prefere o suicídio (Tib. 45).

O vício da avareza (pecuniae parcus ac tenax) (Tib. 46) exige nova analepse (Tib. 47), uma vez que o autor prometera tratar os traços ab exordio (Tib. 42). A centralização da análise em tal vício manifesta-se também na forma como Suetónio desvaloriza actos de liberalidade, ao atribuir carácter de excepção (bis omnino) à ajuda que Tibério dá ao povo, através de um crédito e do reembolso de proprietários de insulae destruídas pelo fogo (Tib. 48.1), e às cidades da Ásia destruídas por um terramoto. ${ }^{16} \mathrm{E}$ a gradação continua: procedente mox in tempore etiam ad rapinas conuertit animum (Tib. 49.1) ("com o decorrer do tempo, voltou também o seu espírito para a rapina"). Nesta perspectiva se aduz uma série de exemplos, apresentados não em sucessão cronológica, mas segundo uma ordem de intensidade: forçou ao suicídio o abastado Gneu Lêntulo ${ }^{17}$; fez condenar Lépida para agradar a Quirínio, homem rico e sem herdeiros ${ }^{18}$; explorou particulares e cidades nas províncias; e, a culminar, espoliou e matou Vonones, rei dos Partos, refugiado com grandes riquezas em Antioquia. Se este facto é anterior aos outros, é colocado no cúmulo da gradação, devido ao agravo: um rei estrangeiro buscava protecção e foi atraiçoado. ${ }^{19}$ Suetónio força a ordem dos factos de modo a sugerir a ligação entre a gradação do ponto de vista moral e cronológico.

A seguir, introduz outra rubrica, na qual trata diacronicamente o odium contra os familiares (Tib. 50.1), para se centrar no relacionamento com a mãe, através de uma longa lista de focos de conflito que culmina na total falta de pietas, manifesta na ausência das exéquias e negação de honras divinas. ${ }^{20}$ Suetónio tenta depois provar que Tibério não tem patria caritas (Tib. 52.1), nem para com o filho biológico, Druso, nem com o adoptivo, Germânico. Fica arredada a hipótese de estas mortes serem a causa do afastamento para Cápreas. ${ }^{21}$ Vão sendo sistematicamente eliminados aos olhos do leitor os melhores traços do retrato de Tibério. Acresce a perseguição até à morte da viúva de Germânico, Agripina (Tib. 53), e dos filhos, Nero e Druso (Tib. 54). Por fim, o âmbito alarga-se: o 
O processo de construção do imagem do tirano ...

ódio contra os antigos amigos e íntimos, conselheiros (Tib. 55) e convidados gregos (Tib. 56).

Neste momento, Suetónio, com uma nova rubrica, introduz mais uma análise retrospectiva para tentar explicar a origem e a evolução da saeua ac lenta natura, que, já na infância, o preceptor de retórica, reconhecia em Tibério e, por isso, Ihe chamava "barro amassado em sangue". Suetónio, como era norma no seu tempo, concebe o carácter como algo inato, embora os vícios se acentuem com a idade. A gradação corresponde ao progressivo abandono da dissimulação:

Sed aliquanto magis in principe eluxit, etiam inter initia cum adhuc fauorem hominum moderationis simulatione captaret.

Mas, uma vez príncipe, manifestou-se muito mais o seu carácter, e mesmo nos começos, quando ainda granjeava o favor das pessoas simulando moderação. (Tib. 57.1)

A seguir introduz-se a aplicação da lex maiestatis, levada até ao ridículo. ${ }^{22}$ A apregoada tolerância de Tibério em relação aos versos satíricos (Tib. 28) parece ser agora posta em causa. ${ }^{23}$ Diz o biógrafo que Tibério, numa primeira fase, os atribuía aos descontentes e repetia: 'Oderint, dum probent!' ("Odeiem-me, desde que me aprovem!"). Mas depois acrescenta: dein uera plane certaque esse ipse fecit fidem ("depois ele próprio tratou de garantir que eram verdadeiros e completamente acertados"). Os versos são, pois, transcritos com intenção caracterológica.

Os versos são, pois, transcritos com intenção caracterológica. Mas o contexto em que surgem é o da crueldade e não da falta de libertas, como se vê pelos capítulos anteriores e seguintes. Com efeito, Suetónio não dá, neste contexto, exemplos de repressão sobre poetas, mas transita para a história do pescador que subira a escarpas para oferecer ao imperador melhor peixe que pescara (Tib. 60). Sem o imaginar, o pescador tinha posto em causa a razão pela qual o imperador apreciava esta ilha: a segurança. A razão do suplício foi o choque sofrido: territus quo is a tergo insulae per aspera et deuia erepsisset ad se ("aterrorizado porque ele escalara, desde a parte de trás da ilha, por escarpas inacessíveis, até junto dele"). ${ }^{24} \mathrm{E}$ a reacção do imperador é desproporcionada.

Chegámos à parte mais cruenta da Vida ${ }^{25}:$ mox in omne genus crudelitatis erupit ("em breve irrompeu em todo o género de crueldades"). Contra a tese da funesta influência de Sejano, Suetónio quer provar que a responsabilidade dos crimes contra os filhos de Germânico recai sobre Tibério, uma vez que ele próprio mandara matar um, quando Sejano já era suspeito, outro, somente depois do temível prefeito ter sido executado. ${ }^{26}$

Entre as características dos tiranos destaca-se, pois, a crudelitas ou saeuitia $^{27}$. O biógrafo, preocupado com a extensão do relato, propõe-se fazer um 
sumário: Singillatim crudeliter facta eius exequi longum est; genera uelut, exemplaria saeuitiae, enumerare sat erit (Tib. 61.2.) ("seguir uma a uma as acções cruéis tornar-se-ia longo; basta enumerar, a título de exemplo, os tipos de crueldades"). A partir daqui, Suetónio, generalizando, transforma casos particulares em procedimentos habituais, como a violação de virgens antes de as estrangular, porque a lei proibia aplicar este castigo a donzelas (Tib. 61.5), situação de que só se conhece o caso da filha de Sejano. ${ }^{28} \mathrm{O}$ clima de terror é acentuado pelas frases, naturalmente exageradas: nemini delatorum fides abrogata. Omne crimen pro capitali receptum (Tib. 61.3) ("não se pôs em dúvida a palavra de nenhum delator. Toda a acusação era considerada capital"). E a gradação continua: Auxit intenditque saeuitiam exacerbatus indicio de morti filii Drusi (Tib. 62.1) ("aumentou e estendeu a sua crueldade, exasperado pela denúncia sobre a morte do seu filho Druso").

A imagem do tirano cruel e misantropo evolui para a condição de odiado e aterrorizado $^{29}$, que o leva a exageradas precauções com os oráculos e com os homens (Tib. 63.2-64). E até a narrativa da desgraça de Sejano é subordinada ao tema do medo de Tibério. O prefeito aparece mais como uma vítima do dolo do imperador (Tib. 65) do que como um conspirador. Tibério envia uma pudenda miserandaque oratio ao senado e, receando um tumulto, prepara navios para o caso de ser necessário fugir. Nem depois de sufocada a conjura se sente mais seguro: não sai da Villa louis durante nove meses. Suetónio apresenta-nos agora uma alma atormentada (anxia mens), fustigada por toda a espécie de injúrias, expressas em libelli e numa carta do rei dos Partos, Artábano (Tib. 66). E, no clímax dos clímaces (indicado por postremo) aparece um Tibério desgostoso consigo próprio (Tib. 67).

Atingido o momento culminante da $V i d a^{30}$, Suetónio faz a descrição geral do biografado. Mas os traços principais continuam presentes nas rubricas do retrato físico, religião e estudos literários. No que respeita à descrição física (Tib. 68.1.2), Suetónio atribui a Tibério os traços dos Cláudios, apresentados no início da Vida. A transição para a descrição psicológica é feita através da rigidez do caminhar, o porte arrogante, o ar sombrio, o jeito taciturno (Tib. 68.1.3). A avisada opinião de Augusto confirma o determinismo biológico: os vícios de Tibério provêm da natureza. ${ }^{31}$ Este determinismo é, de certo modo, agravado pela conviç̧ão de Tibério, derivada do cultivo da astrologia, de que tudo é governado pelo fatum, e, por outro lado, pela negligência em relação aos deuses e práticas religiosas (Tib. 69), a exemplo dos piores tiranos. Mesmo no cultivo das artes liberais, em si um dado positivo, se manifesta o ethos, pela a constatação de que ... adfectatione et morositate nimia obscurabat stilum (Tib. 70.1) ("obscurecia o estilo pela afectação e excessivo rigor"). 
O processo de construção do imagem do tirano ...

\section{Vida de Calígula}

O relato da governação de Calígula começa com factos muito positivos que, ainda que de forma aparatosa, revelam um governante justo. A preocupação do biógrafo, nesta fase, é assinalar uma imagem favorável do filho de Germânico. Mais ainda, o biógrafo parece empreender mesmo uma desculpabilização de certos actos que possam parecer desonrosos. ${ }^{32}$ Mas a violência contra os derrotados do concurso de Lugduno (Cal. 20) prenuncia uma deterioração no comportamento do príncipe.

Se, na narrativa destas acções, o biógrafo diz que tratou quasi de principe $^{33}$ propõe-se, de seguida, tratar de monstro ${ }^{34}$, de modo a sugerir uma transformação radical no comportamento do imperador, mesmo que para isso seja preciso forçar os dados históricos. ${ }^{35}$ Tudo o que para trás se disse de bom se transforma agora num prelúdio ilusório, fruto da dissimulatio, arte que Gaio dominava (Cal. 10.2). Suetónio começa esta parte com as aspirações à usurpação de prerrogativas monárquicas e divinas, sinais de inciuilitas (Cal. 22). Segue-se a impietas para com os antepassados e para com os familiares, a culminar no incesto com Drusila e prostituição das irmãs (Cal. 24). Na mira de obter o efeito desejado - acumular actos do Calígula monstro -, o biógrafo não só desloca a morte da avó Antónia (ocorrida a 1 de Maio 37 d.C.) para a fase negativa do principado (Cal. 23.2), mas entra mesmo em contradição com o que dissera sobre as honras a ela concedidas. ${ }^{36}$

O carácter de Calígula manifesta-se também na forma torpe como faz e desfaz os seus casamentos: o espírito tirânico está patente no arrebatamento das esposas aos maridos (Cal. 25.1). Como no caso de Tibério, a ferocidade manifestase na sua leviandade e frieza em relação a próximos e amigos (Cal. 26), como o seu parente Ptolemeu, neto de Marco António, Mácron e a esposa. Segue-se o desrespeito para com os senadores e os cônsules, e a superbia uiolentiaque com que trata as restantes ordens.

Chegado a este ponto, provada que foi toda a ausência de escrúpulos, o biógrafo trata as demonstrações da saeuitia ingenii no seu mais elevado grau. ${ }^{37}$ Uns capítulos atrás, Suetónio dissera que muitos fizeram votos de combater na arena e de oferecer a própria vida pela saúde do imperador; agora informa que Calígula exige o cumprimento dos votos. O retardamento desta informação é uma consequência da divisão por species, mas também é verdade que a anterior omissão permite aumentar agora o efeito. Sem evitar os pormenores mais cruéis, Suetónio continua a gradatio ${ }^{38}$ e passa a referir os actos acompanhados de palavras (Cal. 29-31). Como Tibério, Calígula parece manifestar consciência da sua psicologia, mas, longe de sentir pesar, mostra-se orgulhoso dos seus defeitos. A sua desfaçatez é expressa em frases onde impera a crueldade e o humor negro, 
características que já vinham associadas no antecessor. Se Calígula dissera que tinha queimado os processos relativos à mãe e aos irmãos, com a garantia de que não os tinha lido, vem agora exibir os documentos de forma ameaçadora. Aparece como um ímpio perjuro, pois jurara pelos deuses que não os lera nem lhes tocara. $^{39}$ Sucedem-se ditos, célebres pela crueldade e pelo humor negro, que culminam no lamento de que nenhuma catástrofe acontecia no seu principado (Cal. 31). Suetónio acrescenta ainda uma rubrica sobre a saeuitia de acções e palavras especificamente em momentos de lazer (Cal. 32-33), ilustrada com outros exemplos terríveis. A gradação continua e os alvos são agora homens de todos os tempos (Cal. 34-35). Além disso, faz-se a transição da superbia e saeuitia para o liuor ac malignitas.

Outra característica usual do tirano é a impudicitia e abuso de matronas e de homens livres. Além do comércio carnal com o pantomimo Mnester e com homens nobres, do incesto com as irmãs e do amor pela cortesã Pirális, diz-se que Calígula não respeitou, à semelhança de Tibério (Tib. 45), nenhuma mulher, por mais ilustre que fosse (Cal. 36.1). Soa a generalização o envio de ordens de divórcio a algumas mulheres em nome dos maridos ausentes de Roma. ${ }^{40} \mathrm{~A}$ dissipação com sumptuosidades (Cal. 37) é outro traço habitual no tirano e tem como consequência a rapina, mascarada sob as mais diversas formas, para fazer face aos gastos (Cal. 38-42): calúnias, leilões, impostos inauditos, exploração, contribuições para o imperador.

A seguir o biógrafo entra na descrição das desconcertantes actividades militares de Calígula (Cal. 43ss), para, no final, retomar o topos da crueldade gratuita - a nefanda atrocitas que o leva a planear dizimar as legiões que se tinham rebelado contra Germânico depois da morte de Augusto. ${ }^{41}$ Uma consequência da tirania em contexto romano é o desrespeito pelo senado. De regresso a Roma, manifesta a hostilidade à altiva ordem (Cal. 49.1). As ofensas ao senado pagam-se caras. O biógrafo diz que Calígula pereceu quatro meses mais tarde, quando projectava crimes ainda maiores, como mudar a corte para Âncio e depois para Alexandria e eliminar os membros mais ilustres da ordem senatorial e dos cavaleiros. ${ }^{42}$ Como evidência destes crimes, Suetónio regista a descoberta de duas listas negras com nomes sugestivos, "o gládio" e o "punhal", e um cofre de venenos (Cal. 49.3).

Mas antes de encetar a narrativa da morte, o biógrafo introduz, como se fez para Júlio César e Tibério, as habituais rubricas sobre o aspecto, o carácter e os interesses de Calígula. Nota-se uma intenção caricatural. ${ }^{43} \mathrm{~A}$ desproporcionalidade e o excesso são comuns ao carácter e ao aspecto físico que o tornam num monstrum. Do retrato físico, Suetónio rapidamente transita para o psicológico, de que o primeiro é um reflexo: Valitudo ei neque corporis neque animi constitit ("nem tinha firme a saúde do corpo nem a da alma"). E a situação 
O processo de construção do imagem do tirano ...

torna-se mais dramática quando o biógrafo faz saber que Calígula tinha consciência do seu estado mental e parecia sofrer com isso: por várias vezes pensou retirar-se para purgar o cérebro. E para tal loucura procuram-se explicações. Corre o boato de que Cesónia Ihe dera um filtro de amor. ${ }^{44}$ Numa tentativa de interpretação das contradições de Calígula, Suetónio atribui a causa do distúrbio mental à conjugação de um atrevimento extremo com um medo exagerado. ${ }^{45} \mathrm{~A}$ rubrica da religio é introduzida no contexto das incoerências do imperador, que, por um lado, despreza os deuses e, por outro, tem horror a trovões. O biógrafo alonga-se a relatar vários exemplos do extremo medo, quer dos fenómenos naturais quer de possíveis ataques de inimigos (Cal. 51.2). A perturbação mental manifesta-se também na indumentária e no calçado. Note-se a construção em clímax, do mais digno para o mais escandaloso:

Vestitu calciatuque et cetero habitu neque patrio neque ciuili, ac ne uirili quidem ac denique humano semper usus est.

Nas roupas e no calçado e no restante trajar não usou o tradicional do seu país, nem o habitual dos cidadãos, nem sequer masculino - e, em suma, nem humano. (Cal. 52)

A indumentária, consonante com a descrição do monstrum, revela o carácter imoral e inumano do imperador, sugere as suas tendências histriónicas e, juntamente com o semblante, representa outro aspecto da quebra das convenções própria do tirano. ${ }^{46}$

Suetónio mostra claramente para onde tendem os interesses de Calígula: desprezo pelas disciplinas tradicionais, dedicação à eloquência e, sobretudo, a outras artes ${ }^{47}$. A progressão do gosto de Calígula pelas artes cénicas e circenses culmina com o favorecimento ad insaniam (Cal. 55.1) do pantomimo Mnéster, dos gladiadores trácios, dos aurigas da equipa dos verdes e sobretudo do seu cavalo, que, segundo o rumor, pretendia elevar à categoria de cônsul (Cal. 55.3). A partir daqui entramos na narrativa da morte. Assim se estabele a relação de causaefeito entre os comportamentos anteriores e o assassínio de que Calígula foi vítima (Cal. $56 \mathrm{ss}$ ): Ita bacchantem atque grassantem non defuit plerisque animus adoriri ("perante tal delírio báquico e tal devastação não faltou a muitos a coragem de o atacar").

\section{Vida de Nero}

Nero retoma e amplia os vícios de Calígula. O biógrafo começa por descrever a parte boa da governação: o tom não é de censura, mas também não é totalmente elogioso, devido à cambiante que denuncia o carácter teatral de ostentação de virtudes: pietas (Nero 9), liberalitas, clementia, comitas (Nero 10.1). Depois da rubrica relativa aos jogos (Nero 11-13), cuja extensão e género de 
espectáculos descritos são reveladores das tendências deste imperador, o biógrafo insere a enumeração dos consulados (Nero 14) e uma espécie de catálogo de medidas justas que contribuem para uma imagem positiva: exercício da justiça (Nero 15); decisões políticas e administrativas (Nero 16-17); regulamentação dos gastos sumptuários - medidas que contradizem o veredicto posterior. ${ }^{48}$ Inclusivamente, Nero é louvado, por um lado, por não desejar expandir o Império, e, por outro, por não retirar da Britânia, demonstrando pietas para com Cláudio (Nero 18).

Subitamente, Suetónio introduz na biografia uma divisão semelhante à que estabelecera na Vida de Calígula. Aos factos que acabara de apresentar, "em parte, não merecedores de repreensão e, em parte, merecedores de um louvor não regateado", opõem-se infâmias e crimes (probra ac scelera) ${ }^{49}$, relatados a seguir. Às desonrosas actividades histriónicas, longamente descritas (Nero 20-25), Suetónio acrescenta uma série de características enunciadas em epígrafe, petulantia, libido, luxuria, auaritia, crudelitas, considerados naturae uitia e não próprios da idade. A progressão é acentuada com a informação de que tais vícios eram exercidos, a princípio, de modo discreto. ${ }^{50}$ Assim se verifica com as saídas nocturnas, à semelhança do que fizera Calígula, e na forma como, durante o dia, se fazia transportar secretamente ao teatro (Nero 26.2). A gradatio na descrição dos vícios implica o retirar da máscara:

Paulatim uero inualescentibus uitiis iocularia et latebras omisit nullaque dissimulandi cura ad maiora palam erupit.

Mas, gradualmente, com o recrudescimento dos vícios, deixou-se de brincadeiras e de mistérios e, sem nenhuma preocupação de dissimular, irrompeu às claras nos maiores excessos. (Nero 27.1)

Entre estes abusos, figuram banquetes fora de horas e orgias (Nero 27.2-3).

Suetónio transita assim para a exploração da libido. 0 desafio às regras e a propensão de Nero para quebrar limites proibidos revela o comportamento tirânico: tem comércio carnal com rapazes de nascimento livre (ingenuorum paedagogia); tem como concubinas mulheres casadas (nuptarum concubinatus); viola a vestal Rúbria (Vestali uirgini Rubriae uim intulit) ${ }^{51}$; pensa em casar com a liberta Acte e trata de arranjar quem declare que é de linhagem real; castra Esporo para o transformar em mulher; deseja o incesto com Agripina (Nero 28.2). A gradação no tratamento da libido atinge o máximo com a prostituição da pudicitia, através de um jogo, em que o imperador se entrega sexualmente a um liberto (Nero 29). Por preferir o que Gascou chama a ordem "intensiva" à ordem cronológica $^{52}$, Suetónio coloca, no cúmulo da gradação, a prostituição da pudicitia. $^{53}$ A homossexualidade passiva, agravada por se tratar, neste caso, de 
O processo de construção do imagem do tirano ...

submissão sexual a uma pessoa de estatuto social inferior, implicava, como é sabido, maior degradação.

A seguir Suetónio entra na descrição da luxuria. No esbanjamento, Nero aproxima-se de Calígula, por quem nutre admiração. ${ }^{54}$ Tal como ele, Nero promove favorecimentos indevidos: ao citaredo Menécrates e ao gladiador Espículo (Nero 30.2). A comitiva das suas deslocações é aparatosa (Nero 30.3). Mas - cúmulo da luxuria e extravagância é a construção da Domus Áurea, ${ }^{55}$ cuja descrição parece assentar nos tópicos da diatribe contra a sumptuosidade. ${ }^{56}$ Tal como Calígula, depois de arruinado, Nero volta-se para a calúnia e para a rapina. ${ }^{57}$ E à semelhança de César, despoja os templos (Nero 32.4. Cf. Jul. 54.3), outro crime típico do tirano retórico. ${ }^{58}$

Os parricidia et caedes de Nero começam com o pater adoptivo (Nero 33.1) e terminam na patria (Nero 38 ). ${ }^{59}$ Primeiro os familiares mais próximos: Cláudio (Nero 33.1), Britânico (Nero 33.2-3), a mãe (Nero 34.1-4), a tia (Nero 34.5), as esposas (Nero 35.1-3). A crueldade levada até ao parricídio, quando está em jogo a conquista do poder, já era tratada nas declamações das escolas de retórica latinas $^{60}$. Suetónio procura tornar Nero cúmplice na morte de Cláudio ${ }^{61}$, ao passo que, no relato da morte deste imperador (Cl. 44), não fora insinuada a cumplicidade do sucessor, mas tão-somente a acção de Agripina. A ideia de que o tirano é, por natureza, parricida tem um modelo trágico em Édipo, um dos papéis que Nero representava. ${ }^{62}$ R. Mayer encontra na narrativa do assassínio de Popeia, com um pontapé, quando ela se encontrava grávida (Nero 35.3), uma tentativa de assimilar Nero a um tirano, Periandro, que, entre outras semelhanças com aquele imperador (como o incesto e o projecto de abertura de um canal no Istmo de Corinto), terá matado, segundo Diógenes Laércio, a esposa grávida, num momento de cólera, com um pontapé (D.L. 1.94). ${ }^{63}$

O círculo alarga-se para a morte de outros familiares ${ }^{64}$ e pessoas ligadas por algum laço de proximidade. ${ }^{65}$ Entre estas mortes são colocadas a do seu expreceptor, Séneca, e a do prefeito do pretório, Burro, seus conselheiros. ${ }^{66}$ Neste processo gradativo passa-se aos crimes contra pessoas de fora da casa imperial e estrangeiros, ${ }^{67} \mathrm{em}$ que se incluem os conspiradores. E a progressão continua ainda com o alargamento do leque das vítimas e das causas do castigo: quem lhe apetecesse e a qualquer pretexto. ${ }^{68}$ Mas as pessoas apresentadas - Suetónio escusa-se de referir os restantes - são figuras gradas, acusadas por motivos políticos: Salvidieno Órfito; Cássio Longino; Trásea Peto. ${ }^{69}$ A culminar, surge o rumor de que dava a comer homens vivos a um polyphagus egípcio (Nero 37.2). Seguem-se exclamações em que Nero, como já antes Calígula, se mostra ébrio do poder ilimitado que possui. ${ }^{70}$

No cúmulo da gradação da crudelitas, figura o atentado contra o povo e contra os muros da patria. ${ }^{71} \mathrm{~A}$ narração, voluntariamente tendenciosa, não só 
apresenta como inquestionável a culpabilidade do imperador no incêndio de 64, suspeita que Tácito põe em dúvida (Tac. Ann. 15.38.1), como procura ainda acentuar o horror com o histrionismo de Nero (Nero 38.2) e rumores infundados de pilhagem. ${ }^{72}$

Porém, Suetónio salienta a notável tolerância de Nero em relação aos ditos e poemas difamatórios (Nero 39.1). Mas nos versos é visível a perda do apoio popular. Sugere-se que, a partir do incêndio, o principado se desagrega: passa-se a narrar o castigo do tirano (Nero 40ss), apesar de, historicamente, Nero ainda governar vários anos: talem principem paulo minus quattuordecim annos perpessus terrarum orbis tandem destituit" ("após ter suportado tal príncipe pouco menos que catorze anos, o orbe da terra destituiu-o finalmente").

\section{Vida de Domiciano}

Quanto a Domiciano, cria-se progressivamente a imagem de um tirano misantropo e cruel: sublinha-se a continuidade entre a natureza, as vicissitudes da vida e a evolução negativa na condução do Império: Circa administrationem autem imperii aliquamdiu se uarium praestitit, mixtura quoque aequabili uitiorum atque uirtutum, donec uirtutes quoque in uitia deflexit: quantum coniectare licet, super ingenii naturam inopia, rapax, metu saeuus (Dom. 3.2). («No que respeita à administração do Império, mostrou-se longo tempo variável, com uma mistura igualmente equilibrada de vícios e virtudes, até que fez mesmo descambar as virtudes em vícios: quanto se pode conjecturar, na sequência das suas inclinações naturais, a carência tornou-o rapace, e o medo tornou-o cruel»). Fica assim sugerida a ideia da correspondência entre uma evolução cronológica e uma evolução psicológica e moral, em que os vícios naturais do imperador se manifestam gradualmente, impulsionados por uma característica psicológica (o medo) e por força das circunstâncias (carência). ${ }^{74}$

Entre os aspectos positivos do principado de Domiciano figura o evergetismo: jogos, distribuições ao povo, banquetes públicos (Dom. 4), política de grandes construções (Dom. 5). Igualmente positivas se consideram as expedições militares contra os Catos, contra os Sármatas e contra os Dacos, relatadas em síntese, como é hábito do biógrafo, ${ }^{75}$ bem como as as medidas administrativas (Dom. 7-9). Ao acentuar uma evolução cronológica de bom para mau, o biógrafo leva o leitor a pensar que todas as medidas positivas acontecem na primeira fase do governo, o que não corresponde à verdade histórica. ${ }^{76}$

Suetónio é impreciso sobre a duração desta fase positiva. ${ }^{77}$ Mas o facto de repetir que este estado de graça acontecia inter initia («nos começos») e aliquamdiu («por algum tempo») (Dom. 9.1), prepara, desde logo, o leitor para uma mudança inevitável. Com efeito, logo a seguir (Dom. 10), o biógrafo pode constatar: Sed neque in clementiae neque in abstinentiae tenore permansit, et 
O processo de construção do imagem do tirano ...

tamen aliquanto celerius ad saeuitiam desciuit quam ad cupiditatem («mas não perseverou nem na clemência nem no respeito pelo alheio, e, no entanto, degenerou muito mais rapidamente para a crueldade que para a cobiça») acentuando a progressão cronológica. ${ }^{78}$ Os casos apresentados falam por si: fez executar um discípulo do pantomimo Páris, pelo simples facto de se assemelhar ao mestre na arte e na beleza; ${ }^{79}$ Hermógenes de Tarso, devido a umas alusões (figurae) na sua história; um pater familias por ter apoiado os gladiadores trácios. ${ }^{80}$ Segue-se uma lista de execuções de senadores e mesmo antigos cônsules em que, para provar que Domiciano é um tirano cruel, se acentua expressamente a futilidade dos pretextos ${ }^{81} \mathrm{e}$ a forma excessiva como reage com base em simples desconfiança. ${ }^{82}$ É a suspeita de conjura que motiva a execução de Cívica Cereal, então procônsul da Síria, ${ }^{83}$ de Salvidieno Órfito ${ }^{84}$ e de Acílio Glabrião, ${ }^{85}$ que estavam no exílio, e de Élio Lâmia. ${ }^{86}$

A técnica adoptada é acentuar a culpa de Domiciano, considerando leves, menores ou até fúteis os crimes dos condenados. Mas as culpas não seriam tão veniais como Suetónio quer fazer crer: a morte de Sálvio Otão Coceiano não se ficaria a dever à celebração pura e simples do aniversário do falecido imperador Otão; ${ }^{87}$ Salústio Luculo não seria certamente morto só por permitir que chamassem "luculiano" a certo tipo de lança; ${ }^{88}$ Flávio Sabino dificilmente terá sido executado apenas pelo erro do arauto que o proclamou imperator, em vez de consul..$^{89}$ Além do mais, existe, em uma das anedotas, amálgama de informação e omissão de um nome: diz-se que Júnio Rústico foi morto por ter escrito as laudes de Trásea Peto e de Helvídio Prisco e os ter apelidado sanctissimi uiri. Ora não consta que Júnio Rústico, autor da laus de Trásea, tenha escrito também uma laus de Prisco - esta seria da autoria de Herénio Senecião, omisso em Suetónio. ${ }^{90}$ Entre as vítimas aparece uma figura que Vespasiano poupara: Métio Pompusiano, a quem um horóscopo anunciava o império. A morte desta personagem acentua $o$ contraste entre a clementia de Vespasiano e a saeuitia de Domiciano. ${ }^{91} \mathrm{E}$ o confronto entre o tratamento benevolente da morte de Helvídio Prisco, no principado de Vespasiano, e a condenação da morte de Helvídio filho, no de Domiciano, lança sobre o biógrafo a suspeita de parcialidade. ${ }^{92}$ Além disso, as mortes apresentadas não pertencerão todas a uma fase adiantada do governo, como o biógrafo pretende fazer crer, ao propor uma evolução cronológica na crueldade do príncipe. ${ }^{93}$

A gradação na saeuitia é datada por referência à guerra civil movida por Lúcio António: Verum aliquanto post ciuilis belli uictoriam saeuior ${ }^{94}$ («Mas tornou-se muito mais cruel depois de sair vitorioso da guerra civil»). A verdade é que, para conseguir a impressão desejada, Suetónio sugere, mais uma vez, uma falsa cronologia: a maioria das mortes anteriormente referidas são certamente posteriores a este marco. ${ }^{95} \mathrm{O}$ biógrafo refere ainda atrocidades, como a invenção 
José Luís Lopes Brandão

de um novos tipos de tortura. ${ }^{96}$ O grau seguinte nesta progressão é o cinismo com que aplicava as penas: Erat autem non solum magnae, sed etiam callidae inopinataeque saeuitia (Dom. 11.1) («Era pois de uma crueldade, não só brutal, mas também astuta e imprevisível»). Já vimos que o humor negro é apanágio dos grandes tiranos. $^{97}$

O biógrafo passa ao tema da rapina, já anunciado atrás. A causa é, como em Calígula e em Nero, a carência das finanças, devido aos gastos com construções, espectáculos e aumento do soldo: ${ }^{98}$ é o reverso da medalha do evergetismo imperial. ${ }^{99}$ A anterior abstinentia (Dom. 9.1), a recusa das heranças da parte de quem tinha filhos vivos (Dom. 9.2), a repressão das fiscales calumniae e o castigo dos delatores, pomposamente ostentado (Dom. 9.3), são anulados agora pela constatação de que bona uiuorum ac mortuorum usquequaque quolibet et accusatore et crimine corripiebantur ${ }^{100}$ ("confiscavam-se os bens dos vivos e dos mortos onde quer que fosse, qualquer que fosse o acusador ou 0 crime»). O facto de se não apresentarem exemplos concretos faz pensar na habitual generalização por parte do biógrafo. Como ponto culminante desta prática de extorsão, Suetónio refere o excesso de rigor posto na colecta do ludaicus fiscus aos judeus (e prosélitos não declarados) que disfarçavam a origem para fugirem ao imposto. O biógrafo atesta a veracidade do facto com o testemunho pessoal (interfuisse me adulescentulum memini): a impressão que lhe causara a inspecção de um nonagenário, na presença de largo conselho, para averiguar se era circunciso. ${ }^{101}$

A seguir, faz-se a apresentação diacrónica da inciuilitas de Domiciano, que, desde a juventude, se mostra arrogante e sem moderação nas palavras e nos actos, ${ }^{102}$ a começar pela desconsideração para com Cénis, concubina de Vespasiano. Os exemplos seguintes lembram de perto os descritos ao longo do capítulo 76 da Vida de Júlio César: facta e dicta que, agravados pela falta de comedimento na aceitação de honras, tornaram justificada a morte do ditador. (Jul. 76.1). Assim se constrói a gradação na actividade de Domiciano como imperador ${ }^{103}$, até se tornar no tirano odiado de todos (Dom. 14.1), altura em que se inicia o relato da morte. $^{104}$

Só depois da narrativa da morte e do funeral aparecem as rubricas descritivas: o retrato físico (Dom. 18), os gostos desportivos (Dom. 19), os estudos liberais (Dom. 20), os hábitos (Dom. 21) e a libido (Dom. 22), com nítido paralelismo estrutural com Nero (Nero 51ss.). Com o físico amolecido, Domiciano é apresentado como um decadente e preguiçoso, incapaz de fazer qualquer tipo de esforço. ${ }^{105}$ Censura-se a negligência revelada nos liberalia studia e afirma-se que só lê os commentarii de Tibério. ${ }^{106} \mathrm{E}$ como é habitual nos tiranos, tem um apetite sexual desmedido. 
O processo de construção do imagem do tirano ...

\section{Vida de Galba}

No que diz respeito aos efémeros imperadores de 68-69 d.C., como o período de governação é muito curto, a gradação não tem a mesma amplitude. Mas, nos casos de Galba e Vitélio, é visível a progressão até um estádio de degradação moral que terá como consequência a morte. A imagem positiva de general austero de que Galba gozava antes da chegada ao poder supremo, e que Ihe garantira a posse do império, esfuma-se. A explicação deste insucesso encontra-a Suetónio no carácter de Galba. Dois vícios se salientam e que, afinal, já eram conhecidos: Praecesserat de eo fama saeuitiae simul atque auaritiae ("Tinham-no precedido a fama, que sobre ele corria, ao mesmo tempo de crueldade e avareza"). ${ }^{107}$ Como habitualmente, os traços negativos do carácter tendem a agravar-se com a ascensão ao poder; e o que era fama torna-se triste realidade: Ea fama et confirmata et aucta est, ut primum urbem introiit (Gal. 12.2) ("Essa fama foi confirmada e agravada, mal entrou na Urbe"). Seguem-se exemplos dos excessos de zelo: despromoveu e dizimou os classiarii, que Nero elevara de remadores a soldados de pleno direito; desmobilizou a coorte da guarda germânica e enviou-a sem recompensa para a sua pátria. Ao encetar a descrição do governo propriamente dito (Gal. 14-16), o balanço pende claramente para o lado negativo:

Maiore adeo fauore et auctoritate adeptus est quam gessit imperium, quanquam multa documenta egregii principis daret; sed nequaquam tam grata erant, quam inuisa quae secus fierent.

Gozou de maior apoio e prestígio ao assumir o império do que ao governálo. Embora desse muitas provas dignas de um príncipe distinto, todavia de modo algum tão gratas como odiosas se tornaram as más acções. ${ }^{108}$

Ora Suetónio não apresenta nenhuma boa acção. ${ }^{109} \mathrm{Em}$ contrapartida, acentua a submissão do imperador a três homens (Tito Vínio, Cornélio Lacão e o liberto Ícelo), já apelidados de "pedagogos" pelo vulgo, e as incoerências daí resultantes: modo acerbior parciorque, modo remissior ac neglegentior quam conueniret principi electo atque illud aetatis ${ }^{110}$ ("ora mais rígido e poupado, ora mais brando e perdulário do que era conveniente para um príncipe eleito e para a sua idade"). As condenações aparecem em catadupa: quosdam claros ex utroque ordine uiros suspicione minima inauditos condemnauit ("condenou alguns ilustres varões de uma e outra ordem, à mínima suspeita, sem os ouvir"). ${ }^{111}$

Galba segue uma política de exagerada contenção, ${ }^{112}$ na qual se vislumbra um esforço para fazer face à dilapidação dos cofres do Estado operada por Nero, mas o biógrafo retém o aspecto negativo do excesso das medidas e a contradição do governo: favorecimentos, castigo de inocentes, impunidade aos 
José Luís Lopes Brandão

culpados, ao ponto de se poupar a vida, contra o pedido do povo romano, a Haloto e Tigelino, agentes de Nero. ${ }^{113} \mathrm{O}$ abuso de poder gera ódio que leva à revolta: Per haec prope uniuersis ordinibus offensis uel praecipua flagrabat inuidia apud milites ${ }^{114}$ ("Com estas acções provocou a hostilidade de quase todas as ordens, mas o rancor ardia principalmente entre os soldados").

\section{Vida de Vitélio}

A actuação de Vitélio como imperador é iniciada com duas medidas consideradas louváveis, que levam o biógrafo a comentar:

egregie prorsus atque magnifice et ut summi principis spem ostenderet, nisi cetera magis ex natura et priore uita sua quam ex imperii maiestate gessisset.

procedia com nobreza, no fim de contas, e com grandeza, ao ponto de criar até a esperança num eminente príncipe, se, quanto ao resto, não agisse mais segundo a natureza e a vida anterior que segundo a majestade do império. (Vit. 10.1)

Logo no campo de batalha de Betríaco, contra as tropas de Otão, tem reacções que o biógrafo qualifica de uanitas e insolentia perante os cadáveres de concidadãos (Vit. 10.3). A semelhança com Nero, cujo modelo Vitélio pretenderia seguir (Vit. 11.2), diz respeito ao que aquele tinha de mais negativo e processa-se não só no plano da actuação política, mas também no moral. Para mais, Vitélio tinha encorajado as ambições artísticas do último dos Júlio-Cláudios (Vit. 4). Como vícios principais, a luxuria e a saeuitia (Vit. 13.1) fazem de Vitélio uma caricatura de Nero. A luxúria concretiza-se na gula, vício no qual ele manifesta a sua desmesura e que também era superlativado por Cláudio ( $C l$. 33.1). O cúmulo deste vício é expresso por homo non profundae modo, sed intempestiuae quoque ac sordidae gulae (Vit. 13.3) («homem não só de uma gula sem fundo, mas também despropositada e abjecta»).

A saeuitia é tal que, pelas semelhanças verbais, corresponde ao grau mais elevado da crueldade de Nero: é exercida contra quem quer que seja e a qualquer pretexto. ${ }^{115}$ Suetónio parece desdobrar informações retiradas de uma mesma história, distribuídas em gradação ao longo da rubrica, com se se tratasse de pessoas diferentes. Conta que, a um doente que, durante um acesso de febre, lhe pedia água, o próprio Vitélio Ihe deu veneno num copo de água fria (Vit. 14.1); a outra vítima, depois de a condenar, mandou reconduzi-la de novo à sua presença e, quando todos celebravam já a sua clemência, ordenou que a matassem à sua frente (Vit. 14.2). Ora a comparação com Tácito parece indicar a utilização de elementos da narrativa da morte de Júnio Bleso. ${ }^{116}$ A tirania manifesta-se também nos jogos, à maneira de Calígula, com quem Vitélio partilhava o gosto pelas 
O processo de construção do imagem do tirano ...

corridas: manda executar uns homens da plebe por terem caluniado a facção azul. ${ }^{117}$ Mas o seu maior ódio era aos bufões e astrólogos. ${ }^{118}$

A semelhança com Nero vai até à acusação de matricídio. Cai sobre Vitélio a suspeição de responsabilidade na morte da mãe, a quem teria negado alimento durante uma enfermidade, movido por um oráculo que lhe prognosticava um longo reinado, se sobrevivesse aos pais. Outros dizem que a mãe, desgostosa da situação do momento e temerosa do que se seguiria, pediu veneno ao filho e que este Iho deu sem se fazer rogado. Este crime marca o auge da sua saeuitia. ${ }^{119}$

\section{Vida de Júlio César}

Um tratamento à parte entre os imperadores tirânicos merece Júlio César. Assegurado o poder de César, sem rivais, Suetónio passa a descrever a tarefa administrativa (Jul. 40-44). ${ }^{120}$ Entre a magnitude dos projectos (que incluem a abertura do istmo de Corinto e a guerra aos partos), surge a primeira referência à morte, como desaire que vem cercear tais planos. ${ }^{121}$ Mas, cumprido o curso da vida, muito há ainda para dizer. Entramos na parte organizada por rubricas: ${ }^{122}$ descrição física e cuidados corporais (Jul. 45.1-2), vestuário (Jul. 45.3), tendência para o fausto e desbaratamento (Jul. 46-47), disciplina doméstica (Jul. 48), impudicitia (Jul. 49), adultérios (Jul. 50-52), moderação no vinho e na comida (Jul. 53), falta de abstinentia nos cargos civis e militares (Jul. 54), eloquentia militarisque res (respectivamente, Jul. 55-56 e 57-70), studium et fides para com os clientes (Jul. 71), facilitas para com os amigos (Jul. 72), prontidão a perdoar as ofensas (Jul. 73), lenitas na vingança (Jul. 74), moderatio e clementia (Jul. 75). Nesta imagem de cambiantes há aspectos bastante positivos que distinguem nitidamente César dos outros tiranos: as qualidades da fides, da facilitas, do perdão e, no clímax, uma extraordinária clemência ${ }^{123}$, comprovada com vários exemplos.

No que respeita à descrição física e aos cuidados com o corpo e com o vestuário, destaca-se o carácter efeminado, consonante com a já analisada narrativa da ligação com Nicomedes (Jul. 49). $O$ abuso das matronas, característico dos tiranos, inicia a descrição dos adultérios ${ }^{124}$, aos quais se associa a sumptuosidade, pelos donativos à amante Servília (Jul. 50.2), pelos gastos com as mulheres das províncias, como entoam os soldados no triunfo ${ }^{125}$, pelos donativos à rainha Êunoe e pela vida faustosa em companhia de Cleópatra (Jul. 52.1). A consequência normal do fausto é a falta de abstinentia (Jul. 54.1), que culmina em rapina e sacrilégio (Jul. 54.2). Nestes aspectos não se diferencia muito de outros tiranos.

Mas César é apresentado acima de tudo como um homem de acção. (Jul. 57 ss). Apesar de se tratar de rubricas, os exemplos apresentados transformam a descrição em narrativa dinâmica que sugere o carácter de excepção da personalidade de César. Suetónio procura mostrar que César é um bom general 
que mantém a disciplina (Jul. 65), que é tolerante nas faltas e rigoroso com desertores e revoltosos (Jul. 67.1), pelo que gera soldados devotados e fortíssimos (Jul. 68). Intercalada, surge a descrição do cavalo (Jul. 61): um animal de pés quase humanos, que não tolera outro cavaleiro, complementa a imagem de um general. Mas o facto de César o criar com cuidado, porque os harúspices tinham prognosticado para o seu dono o imperium orbis terrae, atesta o seu carácter ambicioso. Parece haver aqui uma imitação de Alexandre, que César admirava. Há uma reminiscênica do famoso cavalo do macedónio: Bucéfalo. ${ }^{126}$

A ausência de temor religioso, ao ponto de subordinar a religião aos seus objectivos (Jul. 59), sugere insolência. Mas a alternância de traços de carácter muito negativos com outros muito positivos fazem de César, em parte um tirano, em parte um bom governante. Em suma, se partilha com os tiranos a inciuilitas, uma arrogância perigosa para a República e que o conduzirá aos Idos de Março honras desmedidas, que superam os limites humanos (Jul. 76.1) - a sumptuosidade, a irreligiosidade, a homossexualidade e o abuso de matronas, distingue-se, além da clementia, pela moderação na comida e na bebida - traço que o afasta da moleza decadente dos tiranos nédios e é consonante com a austeridade do general.

\section{Considerações finais}

A construção da imagem destes imperadores segue as linhas gerais do discurso sobre a tirania. O biógrafo procura ilustrar a progressiva manifestação das qualidades próprias dos tiranos e o grau da sua ocorrência. Seria errado acreditar em tudo o que se diz, mas também não seria correcto rejeitá-lo sem mais. As características apontadas correspondem a uma descrição verosímil para os contemporâneos do biógrafo. ${ }^{127}$ Do ponto de vista doutrinal, tomando como exemplo os monarcas helenísticos, todo o tirano evidenciaria à partida inciuilitas, saeuitia ou crudelitas, luxuria, rapacitas, libido exagerada (que inclui abuso de matronas e homens livres, impudicitia e incesto) e impietas contra os deuses, contra a pátria e contra a família (parricídios, matricídios, morte de familiares). E, se não apresentava estas características, conclui-se que as dissimulava: é uma forma cómoda de explicar, sem entrar em contradição, o tradicional período bom de príncipes como Calígula ou Nero. Ora Suetónio, ao escolher das fontes as versões mais romanescas, apresenta narrativas, baseadas muitas vezes em rumores, que correspondem precisamente ao desenvolvimento daquelas características. Combinando estas versões com as técnicas da gradação e da generalização, o biógrafo acentua aqueles traços.

Pelo contrário, a construção progressiva da imagem de um bom imperador assenta na conexão com as virtudes opostas às características dos tiranos: a tónica é colocada nas boas acções, de modo a que os piores comportamentos 
O processo de construção do imagem do tirano ...

sejam relegados para uma fase inicial ou para um plano secundário. A transformação do jovem Octávio, cruel, no magnânimo Augusto tem, pelo contraste, um efeito positivo no leitor. No caso de Vespasiano, além da desculpabilização do vício de avareza, o humor, associado ao carácter afável, contribui para favorecer a imagem do imperador. Os vícios de Tito ficam reduzidos a pecadilhos da juventude, perante uma transformação que se opera quando se torna imperador. Otão transforma-se num bom imperador no derradeiro momento - pela morte corajosa. A biografia de Cláudio distingue-se das restantes, pelos contrastes que ocorrem a cada passo entre aspectos positivos e negativos: o biógrafo procura apresentar (embora injustamente) um imperador incoerente, submetido a mulheres e libertos.

A estrutura das Vidas, organizada em função do carácter, sugere uma progressão que se efectiva na criação gradual de uma impressão na mente do leitor, tendo em vista um final catártico alcançado pela narrativa da morte. Tratase de um tratamento ficcional de factos históricos cujo resultado é naturalmente moralizante. Este efeito é mais forte nas Vidas dos piores dos imperadores, onde a progressão para o vício ultrapassa os limites do suportável. Mas também nos bons governantes há um crescendo na revelação do carácter, organizada, neste caso, de modo a deixar no final uma imagem tanto quanto possível impoluta.

\section{Bibliografia citada}

ALFÖLDY, G. La politique provinciale de Tibère. Latomus, 24, p.824-844, 1965.

BALDWIN, B. Executions, trials, and punishment in the reign of Nero. PP, 22, p.425-439, 1967.

BALDWIN, B. Suetonius. Amsterdam: Hakkert, 1983.

BARRETT, A. A. Caligula. The corruption of power. London / New York: Routledge, 1989 (2000).

BENEDIKTSON, D. Th. Caligula's madness. Madness or interictal temporal lobe epilepsy? CW, 82, p.370-375, 1988.

BLAISON, M. Suétone et l' ekphrasis de la Domus Aurea. Latomus, 57, p.617-624, 1988.

BRADLEY, K. R. Suetonius' Life of Nero. An historical commentary. Bruxelles: Latomus, 1978.

BRANDÃO, J. L. Tirano ao tibre! Estereótipos de tirania nas Vidas dos Césares de Suetónio". Humanitas, 60, p.115-137, 2008.

BRANDÃO, J.L. Máscaras dos Césares. Teatro e moralidade nas Vidas suetonianas. Coimbra, CECH-Classica Digitalia, 2009.

CIZEK, E. Structure et idéologie dans les Vies des douze Césars de Suétone. Paris: Les Belles Lettres, 1977.

COLEMAN, K. M. The emperor Domitian and literature. ANRW, II. 32.5, p.3087-3115, 1986.

COUISSIN, J. Suétone physiognomoniste dans les Vies des XII Césars. REL, 31, p.234-256, 1953.

CROISILLE, J. M. L'art de la composition chez Suétone d'après les Vies de Claude et de Néron. AlIS, 2, p.73-87, 1970.

DELLA CORTE, F. Svetonio eques Romanus. Firenze: La Nuova Italia, 1967. 
José Luís Lopes Brandão

DUNKLE, J. R. The Greek tyrant and Roman political invective of the late Republic. TAPhA, 96, p.151-171, 1967.

DUNKLE, J. R. The rethorical tyrant in Roman Historiography: Sallust, Livy and Tacitus. CW, 65, p.12-20, 1971.

DUPONT, F. ET ÉLOI, T. L'érotisme masculin dans la Rome antique. Paris: Belin, 2001.

EVANS, E. C. Physiognomics in the Roman empire. CJ, 45, p.277-282, 1950.

GALLI, F. Svetonio, Vita di Domiziano. Intr., trad. e comm. Roma: Ateneo, 1991.

GASCOU, J. Suétone historien. Paris: de Boccard, 1984.

GIUA, M. A. Tiberio simulatore nella tradizione storica pretacitiana. Athenaeum, 53, p.352363, 1975.

GIUA, M. A. Sulla biografia suetoniana di Tiberio. Tradizione e struttura. Athenaeum, 56, p.329-345, 1978.

GIUA, M. A. Una lettura della biografia svetoniana di Tiberio. ANRW, II. 33, 5, p. 3733-3747, 1991.

GRELLE, F. La correctio morum nella legislazione flavia. ANRW, II. 13, p.340-365, 1980.

GUASTELLA, G. Gaio Svetonio Tranquillo, La vita di Caligola. Testo, trad. e comm. Roma: La Nuova Italia Scientifica, 1992.

HALLET, J. P. Morigerari. Suetonius, Tiberius, 44. AC, 47, p.196-200, 1978.

HURLEY, D. W. An historical and historiographical commentary on Suetonius'Life of $C$. Caligula. Atlanta: Scholars Pr., 1993

JONES, B. \& MILNS, R. Suetonius: the Flavian emperors. A historical commentary. London: Bristol Classical Press, 2002.

JONES, B. W. Suetonius. Domitian. Ed. with intr., com. and bibl. London: Bristol Classical Press, 1996.

KATZ, R. S. The illness of Caligula. CW, 65, p.223-225, 1972.

KERESZTES, P. The Jews, the Christians and the emperor Domitian. VChr, 27, p.1-28, 1973.

LE ROUX, P. Galba et Tarraco. À propos de Suétone, Galba XII, 1. Pallas, 31, p.113-124 et 192, 1984.

LEVICK, B. Tiberius the Politician. London / New York: Routledge (rev. ed.), 1999.

LINDSAY, H. Suetonius, Tiberius. Edited with intr., com. and Bibliography. London: Bristol Classical Press, 1995.

LOUNSBURY, R. C. Inter quos et Sporus erat: The making of Suetonius' Nero. ANRW, II, 33, 5, p.3748-3779, 1991.

LUCAS, J. Un empereur psychopathe. Contribution à la psychologie du Caligula de Suétone. AC, 36, p.159-189, 1967.

MARTIN, R. Les douze Césars: du mythe à la réalité. Paris: Les Belles Lettres, 1991.

MASSARO, V. \& MONTGOMERY, I. Gaius - Mad, Bad, III, or all Three?. Latomus, 37, p.894909, 1978.

MASSARO, V. \& MONTGOMERY, I. Gaius (Caligula) doth murder sleep. Latomus, 38, p. 699700, 1979.

MAYER, R. What caused Poppaea's death ? Historia, 31, p. 248-249, 1982.

MORFORD, M. P. The distortion of the Domus Aurea tradition. Eranos, 66, p.158-179, 1968.

MORGAN, L. Leui quidem de re... Julius Caesar as tyrant and pedant. JRS, 87, p.23-40, 1997.

MURISON, Ch. L. Suetonius Galba, Otho, Vitellius. Ed. with intr. and notes. London: Bristol Classical Press, 1992. 


\section{O processo de construção do imagem do tirano ...}

OLIVEIRA, F. Biografia dos imperadores em Plínio o Antigo. Biblos, 71, p. 67-84, 1995.

OLIVEIRA, F. La imagen del gobernante ideal en Plinio el Viejo. In: J. A. Sánchez Marín, J. Lens Tuero, C. López Rodríguez (eds.). Historiografía y biografía. Madrid, 1997, p.119138.

SARTORI, A. L'evergetismo dei militari graduati in congedo: in margine a Svet. Tib. 37. MEFRA, 102, p.687-697, 1990.

SEAGER, R. Tiberius. London: Eyre Methuen, 1972.

SOUTHERN, P. Domitian tragic tyrant. London / New York: Routledge, 1997.

STEWART, A. F. To entertain an emperor. Sperlonga, Laokoon, and Tiberius at the dinner table. JRS, 67, p.76-90, 1977.

STOK, F. Ritratti fisiognomici in Svetonio. In: Biografia e autobiografia degli antichi e dei moderni, a cura di Italo Gallo e Luciano Nicastri. Napoli: Ed. Scientifiche Italiane, 1995, p.109-135.

TABACCO, R. Il tiranno nelle declamazioni di scuola in lingua latina. Memorie della Accademia delle Scienze Morali, Storiche e Filologiche di Torino II. Classe di Scienze Morali, Storiche e Filologiche, serie V, vol.9. Torino, p.1-141, 1985.

TOWNEND, G. B. The trial of Aemilia Lepida in A. D. 20. Latomus, 21, p.484-493.

VERDIERE, R. À verser au dossier sexuel de Néron. PP, 30, p.5-22, 1975.

WARDLE, D. Suetonius' Life of Caligula. A commentary. Bruxelles: Latomus, 1994.

WARMINGTON, B. H. Suetonius Nero. Text, with intr. \& notes. Bristol Class. Pr. (2a ed.), 1999.

\footnotetext{
Notas

${ }^{1}$ Na elaboração deste trabalho foi usado diverso material de Brandão (2008, p.115-137; 2009, p.199-252).

${ }^{2}$ Crueldade, avidez e violência sexual são elencados, como traços típicos do tirano, em Quintiliano (Quint. Decl. 329). Vide Tabacco (1985, p.87 e 131). São traços do género dos usados, por exemplo, por Tito Lívio na descrição do famoso Tarquínio-o-Soberbo (Liv. 1.49 ss), por demais arrogante e cruel, ou de Jerónimo, tirano de Siracusa (Liv. 24.5.3-6), de quem se refere, além de arrogância e crueldade, outros elementos significativos, como o uso de trajes sumptuosos, a ostentação de um corpo de guarda-costas e a propensão para uma libido sem precedentes. Vide Dunkle (1971, p.16-17). São termos igualmente usados por Cícero, para classificar as actividades de Verres, Clódio, Pisão, Gabínio ou António, como demonstra Dunkle (1967, p.151-171) e também por uma das fontes de Suetónio, o naturalista Plínio, nos elementos biográficos que sobre os imperadores transmite, como demonstra Oliveira (1995, p.67-84). Vide também Oliveira (1997, p.119-138).

${ }^{3}$ Tib. 30. Cf. Tac. Ann. 1.77.3; 4.6.2.

${ }^{4}$ Vide Giua (1978, p.331; 1991, p.3736).

${ }^{5}$ Exemplar é a repressão da exploração, por parte da plebe de Polência, do evergetismo dos herdeiros de um primipilo, mediante a retenção do seu funeral no foro (Tib. 37.3). Suetónio, ao querer mostrar a desproporção do uso da força (duas coortes entram na cidade de espada em riste e ao som de clarins), parece exagerar, quando diz que Tibério "lançou na prisão, para o resto da vida, a maior parte da plebe e dos decuriões". Vide Sartori (1990, p.687-697).
} 
${ }^{6}$ Suetónio denota gosto por estes acasos que poderiam alterar a história. Para Tac. Ann. 4.59, o acidente não têm importância em si, mas pelas suas consequências políticas: Tibério foi salvo por Sejano, que se torna assim digno de total confiança e todo poderoso, com consequências nefastas na evolução deste principado; vide Gascou (1984, p.419-420).

${ }^{7}$ Tib. 40. Cf. Tac. Ann. 4.57.1; 4.67.1.

${ }^{8}$ Ao passo que Tácito, junta à inacessibilidade o clima temperado e a beleza do lugar (Tac. Ann. 4.67.2).

${ }^{9} \mathrm{O}$ facto de ele se deslocar ao continente (na sequência da derrocada de um anfiteatro que custou a morte de vinte mil pessoas - contra as 50000 referidas por Tácito, Ann. 4.63) e de permitir a aproximação de todos é apresentado como uma grande concessão: Tanto magis, quod urbe egrediens ne quis se interpellaret edixerat ac toto itinere adeuntis submouerat ("Tanto mais que, ao sair da Urbe, publicara um edicto para que ninguém o importunasse, e, em todo o trajecto, mandara afastar os que se aproximavam."). Ao acentuar-se o carácter de excepção de tal facto, o biógrafo cria a imagem de um imperador desconfiado e misantropo. Como outrora em Rodes (Tib. 11), Tibério impõe de novo um exílio a si próprio.

${ }^{10}$ Tib. 41. Vide Levick (1999, p.127-128).

${ }^{11}$ Tib. 42.1. A ideia da mudança na conduta é como que um cliché na tradição sobre os imperadores da dinastia júlio-cláudia. Vide Giua (1975, p.353ss).

${ }^{12}$ Vide Giua (1978, p.331). Sobre o topos da hipocrisia em Suetónio e Tácito, vide Lindsay (1995, p.14) e Giua, 1975, p.352-363).

${ }^{13}$ Como sugerem Dupont e Éloi (2001, p.295). A referência a jovens vestidos de Pãs e ninfas bem como à alcunha de capríneo que o vulgo dá ao imperador (Tib. 43.2) sugere uma sexualidade inspirada na dos sátiros. Tácito (Ann. 6.1) lembra que se trata de crimes tirânicos (more regio) sobre a juventude de nascimento livre.

${ }^{14}$ Tib. 44.1: Maiore adhuc ac turpiore infamia flagrauit, uix ut referri audiriue, nedum credi fas sit.

${ }^{15}$ Tib. 44.2: in qua Meleagro Atalanta ore morigeratur - "no qual Meleagro e Atlante se satisfaziam sexualmente com a boca um ao outro", se aceitarmos a tradução de morigerari no seu sentido médio-passivo de 'estimulação mútua', como propõe Hallet (1978, p.196200). O interesse de Tibério por arte erótica, aliado à especulação sobre as suas actividades em Cápreas, poderá estar na origem da tradição hostil que o representa como um pervertido sexual; assim o afirma Lindsay (1995, p.14 e 142).

${ }^{16}$ Tib. 48.2. Vide Giua (1978, p.341), Alföldy (1965, p.830-831).

${ }^{17}$ Morto em 25 d.C.; cf. Tac. Ann. 4.44.1.

${ }^{18}$ Condenada em 20 d. C. (cf. Tac. Ann. 3.23.1). É um processo complexo; vide Townend (1962, p.484-493).

${ }^{19}$ Tib. 49.2. Segundo Tácito (Ann. 2.68), ele foi assassinado em 19 d. C., na fuga para a Arménia, por um praefectus equitum, sem responsabilização de Tibério. Vide demonstração em Gascou (1984, p.408-410).

${ }^{20}$ Tib. 50.2-51.2. A recusa de honras atribuídas à mãe, interpretada pela tradição hostil como desentendimento, seria uma política oficial de moderação que Tibério também aplicava à sua pessoa. Vide Lindsay (1995, p.151).

${ }^{21}$ Causa apresentada em Tib. 39. Vide Gascou (1984, p.363). 
22 Tib. 58. Tácito (Ann. 1.72.3), remete a orientação de Tibério para a aplicação da lex maiestatis ao ano 15. Vide Giua (1978, p.332; 1991, p.3737).

${ }^{23}$ Tib. 59.2. Giua (1978, p.342-344), aponta várias contradições que ocorrem em Tácito e Suetónio, mas são mais visíveis no segundo, devido à estrutura da biografia: pertenceriam a uma tradição anterior.

${ }^{24}$ Como já vimos, a razão para a escolha da ilha por parte de Tibério é, para Suetónio, a inacessibilidade do lugar: Tib. 40. Cf. Tac. Ann. 4.67.2.

${ }^{25}$ Segundo Giua (1991, p. 3737), só no capítulo 60 se chega verdadeiramente ao período de vícios que fora anunciado no cap. 42, contraposto a toda uma fase precedente de moderação, e se entra na descrição da louca desumanidade de Tibério, desencadeada sem freios no isolamento de Cápreas.

${ }^{26}$ Tib. 61.1. A acção de Sejano provocou actos e palavras de hostilidade por parte das vítimas que não foram obliterados depois da morte, como afirma Levick (1999, p.173). Vide Seager (1972, p.214-215).

${ }^{27}$ Dunkle (1971, p.14-15) nota que, a partir dos últimos anos de Cícero, o termo crudelitas começa a ser substituído por saeuitia na descrição popular do tirano. Acrescenta que o último implica conotações de histerismo e sadismo maníaco, uma vez que primariamente se refere à ferocidade dos animais selvagens. Em Suetónio, prevalece saeuitia. Vide Tabacco (1985, p.89-116).

${ }^{28}$ Cf. Tac. Ann. 5.9.2; Dio Cass 58.11.5. Vide, para este e outros casos de generalização, Gascou (1984, p.452-456).

${ }^{29}$ Tib. 63.1: de inuisus ac detestabilis; praetrepidus; contumeliis obnoxius.

${ }^{30}$ Para a progressão gradativa até ao clímax, vide Cizek (1977, p.124-125). Segundo este autor, tal climax aproxima Tibério, sem o colocar ao mesmo nível, de Calígula e de Nero.

${ }^{31}$ Tib. 68.3: naturae uitia esse, non animi. Vide Martin (1991, p.59-64).

${ }^{32}$ Como o facto de assumir sozinho o terceiro consulado em Lugduno. 0 facto é que o afastamento de Roma o impedira de saber que o colega tinha falecido pouco antes do início do novo ano (Cal.17.1). Semelhante julgamento aparece em Díon Cássio (Dio Cass 59.24.2).

${ }^{33}$ E este quasi (Cal. 22.1), muitas vezes ignorado por tradutores e comentadores, parece sugerir que Suetónio questiona a sinceridade e o mérito das acções de Calígula, como nota Wardle (1994, p.92).

${ }^{34} \mathrm{O}$ termo monstrum sugere uma extraordinária enormidade, estranha às normas naturais, que provoca maravilha ou horror e que pode conter em si o sentido religioso de um presságio. Como acontece em Gal. 18.1: magna et assidua monstra iam inde a principio exitum ei, qualis euenit, portenderant. Monstrum associa-se etimologicamente a moneo. Vide Guastella (1992, p.157).

35 Esta divisão da narrativa em princeps e monstrum é mais o resultado da técnica biográfica de Suetónio (repetida na biografia de Nero, 19.3), do que um dado histórico, uma evolução cronológica. Na primeira fase da biografia, narram-se também acontecimentos que pertencem já a uma fase avançada do governo, como a ponte de Baias (Cal. 19) ou o concurso de Lugduno (Cal. 20). Vide Guastella (1992, p.18-19, e 156-157), Wardle (1994, p.202). Em todo o caso, geralmente aceita-se que houve uma mudança: a um período inicial bom, segue-se depois um mau. Fílon faz coincidir a mudança com a 
doença de 37 (Philo Leg 13); Díon Cássio diz que a mudança ocorre em 38 (Dio Cass 59.2.63.1); Josefo sustém que a mudança ocorre depois de dois anos de bom governo (J. AJ 18.256). Vide Hurley (1993, p.83 e n.41).

${ }^{36}$ É que antes tratava de pietas, mas agora é de impietas. Cf. Cal. 15.2: Post haec Antoniae auiae, quidquid umquam Liuia Augusta honorum cepisset, uno senatus consulto congessit. Vide Gascou (1984, p.365). Só Suetónio fala no boato de envenenamento de Antónia.

37 Cal. 27.1: Saeuitiam ingenii per haec maxime ostendit. Em Cal. 11, fala-se de natura saeua atque probrosa. Cf. Tib. 57.1: saeua ac lenta natura.

${ }^{38}$ Cal. 29.1: immanissima facta augebat atrocitate uerborum.

${ }^{39}$ Cal. 30.2; cf. 15.4. Não é de crer que Suetónio, que tanto cuidado coloca na recolha e análise, se mostre descuidado ou esquecido do que atrás dissera sobre a queima dos processos, como sublinha Wardle (1994, p.86). Suetónio parece querer colocar diante do leitor a progressiva revelação do carácter de Calígula.

${ }^{40}$ Cal. 36.2. Deve tratar-se do caso de Lólia Paulina, esposa de Mémio; cf. Dio Cass 59.12.1. Vide Gascou (1984, p.488, n.145). A abordagem de erotica tem em Suetónio uma função crucial: demonstrar que Calígula viola todas as normas sexuais através da homossexualidade, incesto, adultérios e travestismo. O seu relacionamento sexual prova a sua monstrositas; vide Wardle (1994, p.275), Martin (1991, p.157-158).

${ }^{41}$ Cal. 48.1. A história soa a exagero de Suetónio: poucos ou nenhuns dos soldados envolvidos no motim de 14 estariam ainda ao serviço em 40 . O facto de se dizer que era um projecto levanta a suspeita de que se trataria de um rumor hostil.

${ }^{42}$ Cal. 49.2. A referência antecipada à morte, oito capítulos antes da narração, faz lembrar Jul. 44.4. Também o projecto da mudança da capital para Alexandria, referido no contexto da narrativa da morte, cria um paralelo com Júlio César (Jul. 79.3) e com Nero (Nero 47.2).

${ }^{43}$ Cal. 50.1. Vide Guastella (1992, p.263-264), Gascou (1984, p.607-610). Há quem proponha a influência da tradição fisiognomónica (que Suetónio conheceria) na descrição de Calígula, como pretendem Evans (1950, p.277-282), Coussin (1953, p.234-256), Stok (1995, p.109-135). Colocam sérias reservas à aplicação dos princípios destas teorias às Vidas dos Césares Baldwin (1983, p.500) e Gascou (1984, p.592-598). Vide Wardle (1994, p.323-327). De qualquer modo, é obvio que Suetónio concebia a fealdade física de Calígula como reflexo da desordem psíquica; vide Martin (1991, p.67-70).

${ }^{44}$ Cal. 50.2. Várias são as hipóteses modernas que apontam para uma doença do foro psíquico ou neurológico: vide Lucas (1967, p.159-189), Katz (1972, p.223-225), Massaro e Montgomery (1978, p.894-909; 1979, p. 699-700); contra, vide Morgan (1973, p.327-329). Nem Suetónio nem Dion (Dio Cass 59.8.1-3), consideram a doença significativa para o comportamento do imperador. De resto, Fílon afirma sem hesitar que a doença era estritamente física e que o imperador recuperou completamente (Philo Leg. 16 e 19). Benediktson (1988, p.370-375) defende que Calígula sabia que tinha problemas e que o boato do filtro de Cesónia poderia ter provindo da boca dele próprio. Quando dizia que recorreria à tortura para saber por que razão a amava tanto (Cal. 33), Calígula queria dizer que pensara recorrer à tortura (de escravos, certamente) para apurar se ela lhe tinha dado de facto qualquer afrodisíaco. Vide também Barrett (1989 [2000], p.73).

${ }^{45}$ Cal. 51.1. Vide Baldwin (1983, p.516).

${ }^{46}$ Vide Dunkle (1967, p.170; 1971, p.18-19). 
${ }^{47}$ Ex disciplinis liberalibus minimum eruditioni, eloquentiae plurimum attendit... (Cal. 53.1); sed et aliorum generum artes studiosissime (Cal. 54.1). Trata-se de estabelecer a conexão entre educação e carácter: julgava-se que as disciplinae liberales formavam um carácter virtuoso.

${ }^{48}$ Nero 16.2. A perseguição aos cristãos é colocada aqui entre as medidas boas de Nero e sem qualquer conexão com o incêndio de 64, cuja responsabilidade será mais à frente totalmente imputada ao imperador.

${ }^{49}$ Nero 19.3. Uma fractura na Vida que traz consigo a repartição de alguns episódios entre aspectos positivos e negativos; vide Gascou (1984, p.369-373).

${ }^{50}$ Sensim... et occulte (Nero 26.1). Vide Lounsbury (1991, p.3752).

${ }^{51}$ Nero 28.1. O episódio é duvidoso: vide Verdière (1975, p.7). Vide Martin (1991, p.144) e Warmington (1999, p.54).

${ }^{52}$ Vide Gascou (1984, p.414).

53 Quando, segundo Verdière (1975, p.17-19), o suposto casamento com Doríforo / Pitágoras, em que Nero faz de mulher, teria ocorrido em 64, na altura em que Popeia dá uma filha a Nero, e o casamento com Esporo, em que este coloca o véu, aconteceria entre a morte de Popeia e a viagem de Nero à Grécia (65-66).

${ }^{54}$ Nero 30.1, cf. Cal. 37. Vide Lousbury (1991, p.3755), Gascou (1984, p.370-371).

${ }^{55}$ Nero 31.1: Non in alia re tamen damnosior quam in aedificando domum...

${ }^{56}$ Nero 31.2. Cf. Tac. Ann. 15.42-43. Morford (1968, p.158-179), vê nas descrições da Domus Aurea, em Suetónio e Tácito (Ann. 15.42-43), distorções resultantes da linguagem retórica das declamationes - a diatribe contra a luxuria. Blaison (1998, p.617-624) mostra que a descrição de Suetónio não corresponde à realidade, mas é uma ekphrasis de uma morada sumptuosa, de acordo com uma tradição fixada desde os poemas homéricos.

${ }^{57}$ Nero 32.1: ... calumniis rapinisque intendit animum. Cf. Cal. 38.1; Dom. 12. Esta é uma característica dos tiranos, já manifesta em Júlio César: Jul. 54.3.

${ }^{58}$ Cf. Quint. Decl. 329; Sen. Con. 5.8; 9.4; Quint. Inst. 3.6.78. A descrição retórica do tipo tirânico que delapida o património para satisfazer os seus apetites desmedidos e depois progride para a espoliação dos cidadãos e dos templos encontra fundamento em Platão (Plat. Rep. 9.573 d-575; cf. Arist. Pol. 1305 b 39 ss). Vide Tabacco (1985, p.28-29, 118, n.327).

${ }^{59}$ Vide Lounsbury (1991, p.3753).

${ }^{60}$ Cf. Quint. Decl. 322. Vide Tabacco (1985, p.111).

${ }^{61}$ Cuius necis non auctor, at conscius fuit (Nero 33.1).

${ }^{62}$ A substância doutrinal sobre o tirano à moda grega poderá ter sido introduzida na sociedade romana através da tragédia. Vide Dunkle (1967, p.153-154; 1971, p.12-13). De resto, outras conexões míticas e trágicas são evocadas pelo biógrafo para caracterizar o comportamento de Nero a propósito do matricídio. Divulgam-se escritos que o associam a Orestes e Alcméon (Nero 39.2), e ele próprio se diz perseguido pelas Fúrias (Nero 34.4).

63 Mayer (1982, p.248-249). A comparação do passo com a versão de Tácito e de Díon Cássio indicia um acidente e não uma intenção deliberada de Nero (Tac. Ann. 16.6; Dio Cass 62.27).

${ }^{64}$ Nero 35.4: Nullum adeo necessitudinis genus est, quod non scelere perculerit. 
${ }^{65}$ Nero 35.4: (...) similiter [inter] ceteros aut affinitate aliqua aut propinquitate coniunctos; in quibus Aulum Plautium iuuenem, quem cum ante mortem per uim conspurcasset.

${ }^{66}$ Nero 35.5. O assassínio de Burro é confirmado por Díon, enquanto Tácito hesita entre doença e envenenamento (Dio Cass 62.13.3; Tac. Ann. 14.51.1). Provavelmente nunca se saberá se esta morte teve causas naturais ou se a doença forneceu uma conveniente camuflagem para o assassínio: vide Bradley (1978, p.218).

${ }^{67}$ Nero 36.1: Nec minore saeuitia foris et in exteros grassatus est.

${ }^{68}$ Nero 37.1: Nullus posthac adhibitus dilectus aut modus interimendi quoscumque libuisset quacumque de causa. Segundo Baldwin (1967, p.425-439), não há razão para crer que tenha havido um período de terror no principado de Nero.

${ }^{69}$ Suetónio transforma a morte de Trásea num simples exemplum da crueldade de Nero, deixando de lado toda a perspectiva histórico-política, sublinhada longamente por Tácito (Ann. 16.21-22); vide Gascou (1984, p.436).

${ }^{70}$ Nero 37.3: negauit quemquam principum scisse quid sibi liceret. Cf. Cal. 29.1: 'memento' ait 'omnia mihi et <in> omnis licere.'

${ }^{71}$ Nero 38.1: Sed nec populo aut moenibus patriae pepercit. É interessante o uso do termo patria (raro em Suetónio) que enfatiza a solenidade do momento; a abordagem subjectiva remete para a noção de parricida; vide Bradley (1978, p.227-228), Warmington (1999, p.72).

${ }^{72}$ Nero 38.3: Ac ne non hinc quoque quantum posset praedae et manubiarum inuaderet, pollicitus cadauerum et ruderum gratuitam egestionem nemini ad reliquias rerum suarum adire permisit. Tácito (Ann. 15.43.2) coloca a promessa de remover escombros e cadáveres entre as medidas louváveis de Nero, o que sugere que tanto Tácito como Suetónio usaram a mesma fonte, que era favorável, mas que Suetónio terá manipulado. A proibição de as pessoas se aproximarem dos escombros é uma medida compreensível, dado o perigo de derrocadas. Vide Bradley (1978, p.235) e Warmington (1999, p.73).

${ }^{73}$ Nero 40.1. Cf Cal. 56: Ita bacchantem atque grassantem non defuit plerisque animus adoriri.

${ }^{74}$ Vide Gascou (1984, p.398; 431 e 684), Badlwin (1983, p.298).

75 Dom. 6.1. Uma lista muito incompleta: vide Jones (1996, p.53), Jones e Milns (2002, p.134-135).

${ }^{76}$ Por exemplo, Suetónio sugere indevidamente que a punição da vestal Cornélia e seus cúmplices se situa na fase inicial (Dom. 8.4). Segundo Galli (1991, p.78), o suplício de Cornélia teria acontecido em 89, ou, segundo Grelle (1980, p.347), em fins de 90 ou decurso de 91 . Gascou (1984, p.400), acentua que aconteceu na parte final do principado de Domiciano. Além disso, Suetónio não liga o incestum de Cornélia ao de Domiciano com a sobrinha Júlia, como faz Plínio (Plin. Ep. 4.11). Vide Jones (1996, p.78), Jones e Milns (2002, p.142-143).

77 Vide Baldwin (1983, p.298).

78 Dom. 10.1. Vide Gascou (1984, p.696). Segundo Baldwin (1983, p.487), com esta transição pretende-se salientar a imagem de Domiciano como um segundo Tibério (cf. Tib. 42.1). 
${ }^{79}$ Se o discípulo foi morto, tem de se pressupor - Suetónio não o diz - que Páris, por quem a esposa imperial se apaixonara, foi suprimido por ter sido alvo deste amor. Segundo Díon Cássio, foi morto no meio da rua (Dio Cass 67.3.1).

${ }^{80}$ Dom. 10.1. Domiciano apoiava os mirmilões. Iguais manifestações de partidarismo tirânico em Cal. 32.2 e Vit. 14.3.

${ }^{81}$ leuissima quemque de causa... uerum et ueteres et innoxios iocos (Dom. 10.2). O uso de quod com imperfeito do conjuntivo desvaloriza as razões do imperador: quod ... circumferret quodque indidisset; quod... passus esset; quod... edidisset appellassetque (Dom. 10.3); quod... pronuntiasset (Dom. 10.4).

${ }^{82}$ Como sugerem as expressões: quasi molitores rerum nouarum (Dom. 10.2); quasi... diuortium suum cum uxore taxasset (Dom. 10.4).

${ }^{83}$ C. Vetuleno Cívica Cereal pode ter estado associado ao levantamento do falso Nero no Oriente em 88-89; ou pelo menos Domiciano não acreditou que ele não estivesse: vide Southern (1997, p.104 e 112).

${ }^{84}$ Este foi desterrado em consequência de um processo que envolvia Nerva e Apolónio de Tíanos, como nota Filóstrato (Philostr. VA 7.8; 7.33; 8.7.10). Foi executado mais tarde, talvez por envolvimento em algum tipo de conjura. $O$ facto de o pai dele ter sido executado por Nero, deixaria ressentimento suficiente na família para encorajar uma vingança na pessoa do imperador reinante: vide Southern (1997, p.116).

${ }^{85}$ Segundo Díon Cássio, Acílio Glabrião foi morto, acusado de ateísmo e muitos outros crimes, entre os quais, de combater, como gladiador, com bestas ferozes (Dio Cass 67.14). Os feitos na arena provocaram a inveja do imperador. Há quem tente provar que ele era cristão: vide Southern (1997, p.15).

${ }^{86}$ Dom. 10.2. Domiciano arrebatara-lhe a esposa. É morto por uns ditos de espírito sobre o caso. O ressentimento deve tê-lo atirado para a oposição, e Domiciano, desconfiado, devia temer uma reacção violenta e procurou suprimi-lo: vide Southern (1997, p.116).

${ }^{87}$ Dom. 10.3. Tratava-se da subversiva veneração da memória de um homem que fora imperador: assim se lembraria que o familiar vivo podia aspirar ao principado; vide Galli (1991, p.81-82), Southern (1997, p.116).

${ }^{88}$ Dom. 10.3. Provavelmente teria aderido à revolta de Lúcio António Saturnino em 89, ou poderia ter caído em desgraça pela sua oposição à política não expansionista de Domiciano na Britânia, o que o tornava um potencial traidor aos olhos do imperador, que se mostrava mais consciente dos perigos depois da revolta de Saturnino: vide Jones (1983, p.629-633), Galli (1991, p.82), Jones (1996, p.91), Jones e Milns (2002, p.147).

${ }^{89}$ Dom. 10.4. É suspeita a ligação da morte ao equívoco do praeco, uma vez que T. Flávio Sabino foi designado como colega de consulado de Domiciano para o ano de 82 e viveu o suficiente para ocupar o cargo. Existiria certamente a suspeita de adesão a uma conjura: vide Gali (1991, p.84), Southern (1997, p.43).

${ }^{90}$ Dom. 10.3. Cf. Dio Cass 67.13.2; Tac. Ag. 2; Plin. Ep. 1.5. Segundo Díon, o apelido de santo é apenas atribuído a Trásea (por Aruleno Rústico). Vide Della Corte (1967, p.96-98).

${ }^{91}$ Dom. 10.3. Cf. Ves. 14; Dio Cass 67.12.3. Vide análise das divergências dos relatos em Gascou (1984, p.326-328). Tal como a apresenta Díon Cássio, esta informação devia circular conjuntamente em fontes posteriores à morte de Domiciano (Dio Cass 67.12.2-4). 
92 Helvídio pertence a um grupo, unido por laços familiares e de amizade com um longo historial de oposição estóica: Cecina Peto, Trásea Peto, Helvídio Prisco, Aruleno Rústico, Herénio Senecião, os dois últimos executados por Domiciano e talvez em conjunto com Helvídio filho. No grupo se incluem mulheres como Árria, a heróica esposa de Cecina Peto, e Fânia, filha de Trásea Peto e esposa de Helvídio Prisco filho. Vide Southern (1997, p.113114).

${ }^{93}$ A morte de Flávio Sabino (Dom. 10.4), primo de Domiciano, poderá ser anterior, mas é tomada como a acme do furor assassino de Domiciano, dado o parentesco e o absurdo da causa. Terá sido executado entre 82 e 89 , uma vez que a mulher, a filha de Tito, Ihe sobreviveu (Dom. 22) e morreu, o mais tardar, em 89: vide Galli (1991, p.84), Gascou (1984, p.412-413). Mais provavelmente a execução terá ocorrido, juntamente com a de outros senadores, entre Outubro de 82 e Setembro de 83. Vide Southern (1997, p.43).

${ }^{94}$ Dom. 10.5. A guerra civil aconteceu em Janeiro de 89.

${ }^{95}$ Se tomarmos como referência as datas adoptadas por Gascou (1984, p.411-413, e 691), Cívica Cerial morre por volta de 89; Salvidieno Órfito, por volta de 93; Acílio Glabrião, cônsul com Trajano em 91 (cf. Dio Cass 67.14.3), foi morto em 95; Élio Lâmia em 93 (ou em 85, segundo Galli, 1991, p.59); Métio Pompusiano, talvez em 91; a desgraça de Salústio Luculo é colocada entre 86 e 96 (ou entre 89 e 90, segundo Galli); Júnio Rústico em 93; a expulsão dos filósofos de Itália poderá ter acontecido em 93 (vide Galli, 1991, p.82).

${ }^{96} \mathrm{O}$ facto de o biógrafo não mencionar os nomes destas vítimas pode explicar-se com uma providência de Domiciano que, para abafar o escândalo, proibiu a menção dos nomes nos registos: cf. Dio Cass 67.11.3.

${ }^{97}$ Cf. Cal. 29.1: Immanissima facta augebat atrocitate uerborum.

${ }^{98}$ Dom. 12.1: Exhaustus operum ac munerum inpensis stipendioque, quod adiecerat. Cf. Cal. 38.1; Nero 32.1. Vide Gascou (1984, p.749, n.261). Exhaustus é exagero do biógrafo, como notam Jones e Milns (2002, p.150-151): Domiciano teria recursos suficientes, mas quereria mais (cf. Plin. Pan. 50.5) para o seu programa de construções monumentais.

${ }^{99}$ Ficam assim ensombradas pelo exagero nos gastos medidas anteriormente apresentadas como positivas (Dom. 4-5). Então sublinhou apenas a generosidade do imperador: só agora aborda as consequências nefastas; vide Gascou (1984, p.372).

${ }^{100}$ Dom. 12.1. Esta atitude contrasta com a de Tito, que desencoraja e castiga os delatores (Tit. 8.5), e faz lembrar a de Nero, pela repressão indiscriminada: Nullus posthac adhibitus dilectus aut modus interimendi quoscumque libuisset quacumque de causa (Nero 37.1).

${ }^{101}$ Dom. 12.2. Suetónio faz referência à taxa da didracma, que os Judeus já pagavam para o templo de Jerusalém e, que, depois da destruição deste, no ano 70, passaram a pagar para o templo de Júpiter Capitolino, o que Ihes dava o direito de praticarem livremente a sua religião: cf. J. BJ 7.6.6; Dio Cass 66.7.2. Vide Keresztes (1973, p.1-7), Galli (1991, p.86-88).

102 Dom. 12.3: Ab iuuenta minime ciuilis animi confidens etiam et cum uerbis tum rebus immodicus. Vide Martin (1991, p.312-313).

${ }^{103}$ Cizek (1977, p.120), não concorda que haja gradações na Vida de Domiciano. Segundo este autor, o biógrafo prefere apresentar uma imagem de matizes.

${ }^{104}$ Per haec terribilis cunctis et inuisus, tandem oppressus est $<\ldots . .>$ amicorum libertorumque intimorum simul et uxoris (Dom. 14.1). É notável o paralelismo com as Vidas de Calígula e de Nero: Cal. 56.1; Nero 40.1. Vide Croisille (1970, p.78, n.5), Gascou (1984, p.790). 
${ }^{105}$ Dom. 19. A mesma ideia em Tac. Ag. 40; Plin. Pan. 14; Dio Cass 67.6.3.

106 Dom. 20. As críticas de Suetónio parecem injustas. Coleman (1986, p.3087-3095), sustenta que Domiciano teria talento literário, mas, ao chegar ao poder, terá revelado uma conscienciosa preocupação com o governo e legislação, facto que o levou a abandonar a actividade literária.

107 Gal. 12.1. Para Le Roux (1984, p.113-124), Suetónio mostra-se dividido entre a aprovação da revolta de Galba contra Nero e a condenação dos excessos que provocou por culpa do carácter do imperador e do contexto de guerra civil.

$108 \mathrm{Gal}$. 14.1. Cf. Tac. Hist. 1.7.2. A ideia de que era um bom cidadão privado e um mau imperador também vem expressa em Tácito: et omnium consensu capax imperii, nisi imperasset (Tac. Hist. 1.49.4).

${ }^{109}$ Tácito e Díon Cássio expõem as boas acções (Tac. Hist. 1.49. Dio Cass 64.2.1-3.4).

${ }^{110}$ Gal. 14.2. Cf. Tac. Hist. 1.13.1. Vide Martin (1991, p.286-287).

${ }^{111} \mathrm{Gal}$. 14.3. Cinco expressões (quosdam - claros - ex utroque ordine - suspicione minima inauditos) apresentadas em gradação emotiva, que sugerem a imagem de um tirano sedento de sangue Como salienta Murison (1992, p.68), o propósito desta enumeração não é restringir a referência através de uma definição cuidadosa, mas criar a impressão de tirania crescente e sangrenta.

${ }^{112}$ Gal. 15.1. Cf. Plutarco. Gal. 16. 3-4; Tac. Hist. 1.20.

${ }^{113} \mathrm{Gal}$. 15.2. Mas Suetónio silencia a eliminação, com o aplauso do povo, de vários agentes de Nero, como se vê pelo confronto com Plutarco, Gal. 17.2-3, e Dio Cass 63.3.4.

${ }^{114} \mathrm{Gal}$. 16.1. Esta afirmação sugere que a queda de Galba é uma consequência directa da conduta anterior. Suetónio costuma colocar a supressão dos imperadores em explícita relação com a conduta precedente: cf. Jul. 76.1; Cal. 56.1; Nero 40.1; Dom. 14.1. Vide Cizek (1977, p.129-130).

${ }^{115}$ Vit. 14.1: Pronus uero ad cuiuscumque et quacumque de causa necem atque supplicium; cf. Nero 37.1: Nullus posthac adhibitus dilectus aut modus interimendi quoscumque libuisset quacumque de causa. Contrasta com esta afirmação de Suetónio a notícia, dada por Díon Cássio, de que suprimiu reduzido número de otonianos (Dio Cass 66.6.2).

${ }^{116}$ Tac. Hist. 3.39.1. Vide Murison (1992, p.162-163).

117 Vit. 14.3. Também Calígula se ofende por a plebe apoiar outra equipa: Cal. 30.2. Domiciano condena um indivíduo que apoia os gladiadores Trácios (Dom. 10.1).

118 Vit. 14.4: Nullis tamen infensior quam uernaculis et mathematicis.

119 Vit. 14.5. Tácito dá notícia de uma opportuna mors, ocorrida poucos dias antes da de Vitélio (Tac. Hist. 3.67.2). Sobre a organização em clímax (Vit. 12-14), vide Cizek (1977, p.132-133).

${ }_{120}$ Jul. 40.1: Conuersus hinc ad ordinandum reipublicae statum...

$121 \mathrm{Jul}$. 44.4: Talia agentem atque meditantem mors praeuenit.

$122 \mathrm{Jul}$. 44.4: De qua prius quam dicam, ea quae ad formam et habitum et cultum et mores, nec minus quae ad ciuilia et bellica eius studia pertineant, non alienum erit summatim exponere.

$123 \mathrm{Jul}$. 75.1: Moderationem uero clementiamque cum in administratione tum in uictoria belli ciuilis admirabilem exhibuit. 
José Luís Lopes Brandão

124 Jul. 50.1: Pronum et sumptuosum in libidines constans opinio est, plurimasque et illustres feminas corrupisse.

125 Jul. 51: Aurum in Gallia effutuisti, hic sumpsisti mutuum.

${ }^{126}$ Cf. Plut. Alex. 61.

${ }^{127}$ Vide Dupont e Éloi (2001, p.263-323). 